\title{
Preparing for Disasters: Your food and drinking water supply ${ }^{1}$
}

Amy H. Simonne ${ }^{2}$

\section{Preparing Your Drinking Water}

Having enough clean drinking water is a top priority during any emergency! A normally active person needs at least two quarts of water each day. However, needs vary depending on the weather and an individual's age and health status. When clean water is not available, we need to purify all water before using it for drinking, preparing food, or personal hygiene. Many methods for purifying water are available, but none (by itself) is perfect. Often, a combination of more than one methods works best.

\section{Three Ways to Purify Water}

1. Boiling is the safest and most reliable method to make water safe to drink.

- Bring water to a vigorous boil (3-5 minutes), and then allow it to cool.

- Boiled water will taste better if you add oxygen back in by switching back and forth between two CLEAN containers.

2. Chemical disinfection can be used when power or fuel for boiling is not available.

- Liquid household bleach can be used to kill microorganisms. Use only regular bleach with 5.25 percent sodium hypochlorite. (Do NOT use colorsafe bleach or bleach with scent or added cleaners.) Add 16 drops of bleach per gallon of water: Stir. Let stand for 30 minutes. Smell the water. If you don't smell a slight bleach odor, add another dose of bleach and let stand another 15 minutes.

- Tincture of iodine and tetraglycine hydroperidoide tablets are recommended when liquid household bleach is not available. The tincture of iodine can come from a medicine chest or first -aid kit. Tetraglycine hydroperidoide tablets are available from pharmacies and sporting goods stores. Follow manufacture's instructions. For clear water, use one drop of $2 \%$ tincture of iodine per quart or liter of water. Water must stand for a minimum of 30 minutes before it is safe to use. For cold or very cloudy water, ten drops of $2 \%$ tincture of iodine are required. The water should be allowed to stand several hours before use. To ensure that Cryptosporidium is killed, water must stand for 15 hours before drinking.

IMPORTANT NOTE: Chemically treated water is intended for short-term use only. If iodine-disinfected water is the only water available, it should be used for only a few weeks.

1. This document is FCS9195, one of a series of the Department of Family, Youth and Community Sciences, Florida Cooperative Extension Service, IFAS, University of Florida, Gainesville FL 32611. First published: May 2003. Reviewed by Elizabeth Bolton, Ph.D., and Linda Bobroff, Ph.D.,RD, LD/N, Department of Family, Youth and Community Sciences. Please visit the EDIS Web site at http://edis.ifas.ufl.edu

2. Amy H. Simonne, Ph.D., assistant professor, Department of Family, Youth and Community Sciences, University of Florida, Gainesville FL 32611. 
3. Distillation involves boiling water and collecting the vapor. It removes microbes, heavy metals, salts, and most other chemicals. The American Red Cross document has a method for distilling water.

\section{Preparing Your Food Supply}

Preparation for emergency food supplies can be simple if it is done before the emergency occurs. Although individual and family needs vary anyone can use the following general tips to build a food supply for emergency situations.

- Length supply: Several resources are available on how to prepare food supplies for various lengths of times such as three days, seven days or two weeks.

- Nutritional considerations: Include a variety of foods to maintain nutritional needs, and for other special considerations; include foods that are familiar to you and your family.

- Foods should need little or no energy to keep or prepare: Foods should not need to be refrigerated, or frozen or need cooking. These include many canned, dried, and other non-perishable foods.

- Balancing water and food supplies: If the water supply is limited, avoid foods that are high in fat, protein or salty. Omit foods that need large quantities of water to prepare.

- Equipment and utensils: Keep a can opener, a pair of scissors and disposable utensils in your emergency kit.

For additional information, check out the following resources provided.

\begin{tabular}{|c|c|c|}
\hline Publication (source) & Description & Contact information \\
\hline $\begin{array}{l}\text { Emergency Food and Water } \\
\text { Supplies (FEMA-215) }\end{array}$ & $\begin{array}{l}\text { - How to store water } \\
\text { - Outdoor water sources } \\
\text { - Short-term food supplies } \\
\text { - Food and water storage } \\
\text { tips } \\
\text { - Nutrition tips } \\
\text { - How to purify water } \\
\text { - Disaster supplies }\end{array}$ & $\begin{array}{l}\text { Call Local American Red } \\
\text { Cross Chapter or Write to } \\
\text { FEMA } \\
500 \text { C Street, SW Washington, } \\
\text { D.C. } 20472 \text { (202) 566-1600 }\end{array}$ \\
\hline $\begin{array}{l}\text { Home Emergency Supplies } \\
\text { (American Red Cross) }\end{array}$ & $\begin{array}{l}\text { - Mini survival kit for car } \\
\text { - How to store emergency } \\
\text { supplies }\end{array}$ & $\begin{array}{l}\text { Local American Red Cross } \\
\text { Chapter }\end{array}$ \\
\hline $\begin{array}{l}\text { Your Family Disaster Supplies } \\
\text { Kit (FEMA) }\end{array}$ & $\begin{array}{l}\text { Describes how to put together } \\
\text { your kit: } \\
\text { - Water, Food } \\
\text { - First Aid Kit } \\
\text { - Supplies }\end{array}$ & $\begin{array}{l}\text { Write FEMA P.O. Box } 70274 \\
\text { Washington, D.C. } 20024 \\
\text { FEMA L - 189, ARC } 4463 \\
\text { Or visit FEMA.gov }\end{array}$ \\
\hline $\begin{array}{l}\text { Emergency Food and Water } \\
\text { Supplies (FEMA) }\end{array}$ & $\begin{array}{l}\text { - Water purification } \\
\text { - Preparing an emergency } \\
\text { stockpile }\end{array}$ & $\begin{array}{l}\text { FEMA, } 500 \text { C Street, } \\
\text { SW Washington, D.C. } 20472 \\
\text { Phone: (202) 566-1600 }\end{array}$ \\
\hline
\end{tabular}




\begin{tabular}{|c|c|c|}
\hline Publication (source) & Description & Contact information \\
\hline $\begin{array}{l}\text { Resources for Food } \\
\text { Safety and Storage in } \\
\text { Emergency Situations } \\
\text { (FINC) }\end{array}$ & $\begin{array}{l}\text { - List of brochures and } \\
\text { fact sheets on food } \\
\text { safety } \\
\text { - Seven day food supply } \\
\text { list } \\
\text { - List of cookbooks to } \\
\text { use during } \\
\text { catastrophic time }\end{array}$ & $\begin{array}{l}\text { Food and Nutrition Information Center } \\
\text { National Agricultural Library/USDA } \\
10301 \text { Baltimore Avenue, Room } 304 \\
\text { Beltsville, MD 20705-2351 or } \\
\text { http://www.nal.usda.gov/fnic/emerg.html }\end{array}$ \\
\hline
\end{tabular}

\section{References:}

Travelers's Health: Risks from Food and Drink (CDC, 2003). Http://www.cdc.gov/travel/food-drink-risks.htm Emergency Food and Water Supplies (FEMA-215)[Updated June 16, 1998].

Http://outlands.tripod.com/survial/fema-215.htm 